Published by Al-Nahrain College of Medicine P-ISSN 1681-6579

E-ISSN 2224-4719

Email: iraqijms@colmed-alnahrain.edu.iq

http://www.colmed-alnahrain.edu.iq

http://www.iraqijms.net

Iraqi JMS 2019; Vol. 17(2)

\title{
Acute and Subacute Toxicity of Chloroform Extract of Xanthium strumarium Leaves
}

\author{
Atheer S. Alsabah ${ }^{1} P h D$, Abdulkareem H. Abd ${ }^{2} P h D$, Ahmed M. Al-Shammari ${ }^{3} P h D$ \\ ${ }^{1}$ Dept. of Pharmacology and Toxicology, College of Pharmacy, Al- Mustansiriyah University, Baghdad, Iraq, ${ }^{2}$ Dept. of \\ Pharmacology, College of Medicine, Al-Nahrain University, Baghdad, Iraq, ${ }^{3}$ Iraqi Centre for Cancer and Medical Genetic \\ Researches, Al-Mustansiriyah University, Baghdad, Iraq
}

\begin{abstract}
Background The incidence of cancer is increasing worldwide. Xanthium strumarium may possess anticancer activity, the plant extract for in vitro anticancer activity against a panel of three human cell lines (Breast MCF7, Renal TK10 and Melanoma UACC62), exhibit anticancer activity against these three human cell lines screened by National Cancer Institute.

Objective To investigate the safety of chloroform extract of Xanthium strumarium leaves, which showed potent cytotoxic activity against tumor cells.

Methods The leaves were dried and grounded into fine powder, and extracted with chloroform, that showed potent cytotoxic activity has been tested against two animal species mice and rats for testing its safety. Toxicity was evaluated in Swiss albino mice by feeding with serial doses of extract between 1.0 to $20.0 \mathrm{gm} / \mathrm{kg}$ orally and observed continuously for the first $4 \mathrm{hr}$ and hourly for the next $24 \mathrm{hr}$, then every $6 \mathrm{hr}$ for $48 \mathrm{hr}$ (72 hr, acute toxicity). Rats were also fed with extract single dose of 5 $\mathrm{gm} / \mathrm{kg}$, the toxicity was carried out by assessing the effects on biochemical parameters, body weight and relative organ weights for both male and female rats.

Results $\quad \mathrm{LD}_{50}$ of chloroform extract was $3.07 \mathrm{gm} / \mathrm{kg}$. The biochemical finding showed no significant differences compared to control. No significant weight changes occur throughout the study.

Conclusion Chloroform extract has low $\mathrm{LD}_{50}(3.07 \mathrm{gm} / \mathrm{kg})$, but the acute toxicity study showed no mortality or signs of toxicity, with non-significant changes in body weights, relative organ weights, and biochemical tests among treated groups compared to their controls.

Keywords Citation Xanthium strumarium, chloroform extract, cytotoxic herb, acute toxicity

Alsabah AS, Abd AH, Al-Shammari AM. Acute and subacute toxicity of chloroform extract of Xanthium strumarium leaves. Iraqi JMS. 2019; 17(2): 108-113. doi: 10.22578/IJMS.17.2.3
\end{abstract}

List of abbreviations: None

Introduction

X anthium strumarium L. (Family: Compositae) a medicinal plant commonly found as a weed. It has several health promoting benefits including; antibacterial, antifungal, antimalarial, antiinflammatory, antihypoglycaemic, diuretic, analgesic, antioxidant, antitumor, anticancer, antimitotic, and insecticidal activities ${ }^{(1,2)}$.

Xanthium strumarium may possess antimitotic components. In a study, the plant was screened for its antimitotic activity using the microtubule-tubulin system isolated from mammalian tissue. The separated fractions obtained were identified and used for in vitro polymerisation studies. The whole as well as partially separated chemical constituents showed effective inhibition of tubulin 
polymerization (3). Also possesses anticancer activity. Two xanthanolide sesquiterpene lactones, 8-epi-xanthatin and 8-epi-xanthatin$5 \beta$-epoxide, isolated from the leaves demonstrated significant inhibition on the proliferation of cultured human tumor cells, i.e. A549 (non-small cell lung), SK-OV-3 (ovary), SKMEL-2 (melanoma), XF498 (CNS) and HCT-15 (colon) in vitro. They were also found to inhibit the farnesylation process of human lamin-B by farnesyl transferase, in a dose-dependent manner in vitro ${ }^{(1)}$. $L_{50}$ is represent standard measures for acute toxicity, it stated in $\mathrm{mg}$ of herbal crude extracts per $\mathrm{kg}$ of the weight of tested animals. This dose considered the single dose that kill $50 \%$ of total tested animals. The lower $\mathrm{LD}_{50}$ dose, the higher toxic substance ${ }^{(4)}$. $\mathrm{LD}_{50}$ as a mean for identifying the required dose for in vivo experiment and latterly clinical trials; as the starting dose is $10 \%$ of $\mathrm{LD}_{50}{ }^{(5)}$. Moreover, acute toxicity account for more than identifying the lethal dose but goes further to identify the changes that may the administered herb produce in the animals. Rats were used for acute toxicity while mice were used in $L_{50}$ identification, in order to achieve 2 different species at least to be tested for identifying the acute toxicity ${ }^{(6)}$.

The aim of this study is to investigate the safety of chloroform extract of Xanthium strumarium leaves.

\section{Methods}

\section{Extraction}

Fresh leaves of Xanthium strumarium were collected in August 2016 from farms (Salamiyat county, Baghdad, Iraq) and authentication was done in Pharmacognosy and Medicinal Plants Department, College of Pharmacy, Mustansiriyah University prior of purchasing. The leaves were cleaned and shade dried at room temperature, then grinded into fine powder. The total of $600 \mathrm{~g}$ powder was divided into four equal parts and extracted via chloroform in a ratio of 1:4 W/V (150 g powder $1600 \mathrm{ml}$ solvent), for $24 \mathrm{hr}$ by shaking water bath at $40{ }^{\circ} \mathrm{C}$, then Whittman no.1 filter paper used for isolating the pure extract. Vacuum rotary evaporator was used for concentrating and obtaining the final crude extract, that dried under stream of cold air, and weighed to determine the yield. Extraction process repeated three times and the extract kept in desiccators at room temperature prior to the experiment ${ }^{(7)}$.

\section{LD $_{50}$ study}

The toxicity study was carried out using seventy Swiss albino mice (35 male and 35 female) weighing 20-25 g each. The animals were randomly distributed into one control group and six treated groups (for each sex), containing five animals per group, provided with water and food and were allowed to adapt to the laboratory conditions for seven days before the experiment. After depriving the animals' food overnight, the control group received $0.3 \mathrm{ml}$ of $2 \%$ Tween 80 solution orally while each treated group received orally chloroform extract of Xanthium strumarium leaves; prepared by dispersing $8.0 \mathrm{~g}$ in 10 $\mathrm{ml}$ volume of $2 \%$ Tween 80 in the doses as follows: 1.0, 2.5, 5.0, 10.0, 15.0 and $20.0 \mathrm{~g} / \mathrm{kg}$ $(8,9)$. The animals were observed continuously for the first $4 \mathrm{hr}$ and hourly for the next $24 \mathrm{hr}$ and every $6 \mathrm{hr}$ for the following $48 \mathrm{hr}$ after administering of the extract, to observe any death or changes in general behavior and other physiological activities (10,11). The study has been approved by the Institutional Review Board of College of Medicine, Al-Nahrain University, Baghdad, Iraq.

\section{Acute toxicity study}

The acute oral toxicity was evaluated following the World Health Organization (WHO) guideline ${ }^{(12)}$. Twenty Albino rats (10 males and 10 females) were divided into one control group and one treated group (for each sex), containing five animals per group. The treated groups were orally given the extract in a single dose of $5 \mathrm{~g} / \mathrm{kg}$ body weight, while the control groups received only water vehicle. The animals were monitored for apparent signs of toxicity for 14 days. The animals that died within this period were subjected to 
necropsies. All rats were sacrificed on the $14^{\text {th }}$ day of experiment.

\section{Experimental design and analysis of data}

The experiment design used for this study was Rationalized Complete Block Design (RCBD). The results were reported as mean \pm standard deviation (SD). One-way analysis of variance (ANOVA) followed by Tukey test comparison ttest (2-tailed) was used to compare between treatments groups. The differences between the means are considered significant at the 5\% confidence level. The statistical analysis was carried out by using SSPS 16.0, the level of significance was set at $\mathrm{P}<0.05$.

\section{Results}

$\mathrm{LD}_{50}$ determination for chloroform extract of Xanthium strumarium leaves on mice

Table 1 shows the number of dead and survive mice for male and female mice. Different doses of chloroform extract have been administered for each group of mice. Figure 1 shows the $\mathrm{LD}_{50}$, which represent the dose required to kill fifty percent of total treated mice.

Table 1. The number and percentage of dead mice in variant groups with different administered doses

\begin{tabular}{|c|c|c|c|c|}
\hline Group & $\begin{array}{c}\text { Dose of } \\
\text { extract }(\mathrm{g} / \mathrm{kg})\end{array}$ & $\begin{array}{c}\text { No. of mice } \\
\text { (male \& female) }\end{array}$ & $\begin{array}{c}\text { No. of dead } \\
\text { mice }\end{array}$ & $\begin{array}{c}\text { Dead mice } \\
\text { cumulative (\%) }\end{array}$ \\
\hline \multirow{2}{*}{ Control } & \multirow{2}{*}{0} & 5 males & 0 & 0 \\
\hline & & 5 females & 0 & 0 \\
\hline \multirow{2}{*}{1} & \multirow{2}{*}{1} & 5 males & 2 & 40 \\
\hline & & 5 females & 1 & 20 \\
\hline \multirow{2}{*}{2} & \multirow{2}{*}{2.5} & 5 males & 3 & 60 \\
\hline & & 5 females & 2 & 40 \\
\hline \multirow{2}{*}{3} & \multirow{2}{*}{5} & 5 males & 3 & 60 \\
\hline & & 5 females & 3 & 60 \\
\hline \multirow{2}{*}{4} & \multirow{2}{*}{10} & 5 males & 5 & 100 \\
\hline & & 5 females & 4 & 80 \\
\hline \multirow{2}{*}{5} & \multirow{2}{*}{15} & 5 males & 5 & 100 \\
\hline & & 5 females & 4 & 80 \\
\hline \multirow{2}{*}{6} & \multirow{2}{*}{20} & 5 males & 5 & 100 \\
\hline & & 5 females & 5 & 100 \\
\hline
\end{tabular}

Acute toxicity study for chloroform extract of Xanthium strumarium leaves on rats

After the rats were orally given a single dose 5 $\mathrm{g} / \mathrm{kg}$, neither mortality nor signs of toxicity were observed during 14 days of the acute toxicity experiment. The alterations of body weight and relative organs weight from the control would reflect the toxicity of the substance, there was no significant difference in relative organs weight between treated rats and their controls with the absence of any morphological changes. Table 2 shows the body weight changes during the experiment period for male and female rats. Data expressed as mean $\pm S D$, each group has five rats. The weigh for male and female rats were measured every seven days. Table 3 shows the relative organs weight for male and female rats. Table 4 shows the changes in serum profile for the treated rats in comparison to their controls. There were no significant differences between groups (male and female) relative to their controls $(P>0.05)$. 


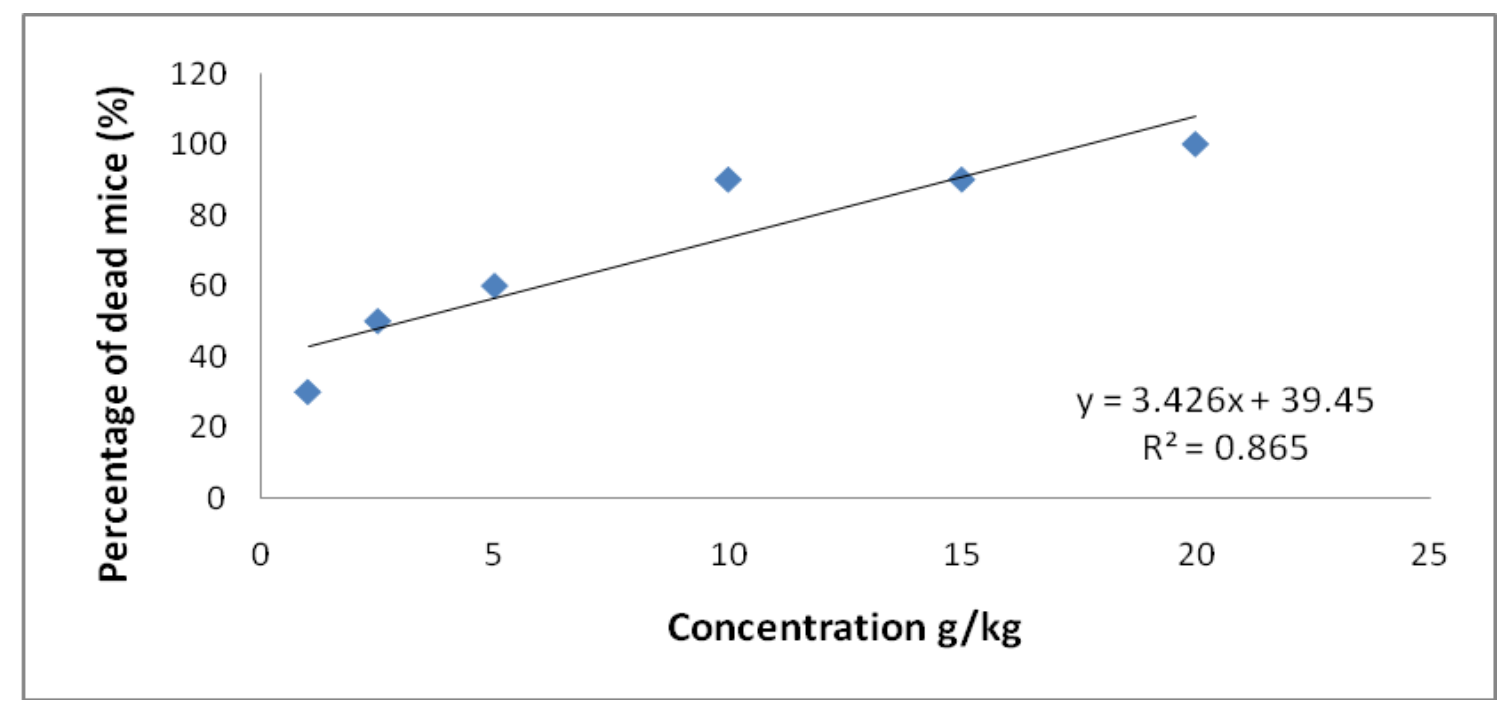

Figure 1. The $L D_{50}$ of chloroform extract of Xanthium strumarium leaves on mice. The $L_{50}$ calculated through the equation $y=3.426 x+39.45$ and it was $3.07 \mathrm{~g} / \mathrm{kg}$

Table 2. The animals' weight (g) of treated groups compared to their controls during fourteen days of the acute toxicity experiment, the data showed no significant weight reduction in animals $(P>0.05)$. The changes in weight represented by mean $\pm S D, n=5$

\begin{tabular}{ccccc}
\hline \multirow{2}{*}{ Time (day) } & Male & Male control & Female & Female control \\
\hline Day 0 & $200.8 \pm 26.6$ & $209.0 \pm 17.8$ & $203.0 \pm 17.1$ & $199.0 \pm 26.3$ \\
Day 7 & $192.0 \pm 12.5$ & $212.6 \pm 17.1$ & $201.0 \pm 15.9$ & $199.0 \pm 18.7$ \\
Day 14 & $180.4 \pm 20.8$ & $222.8 \pm 26.0$ & $189.8 \pm 22.1$ & $204.0 \pm 34.3$ \\
\hline
\end{tabular}

Table 3. Relative organs weight ( $\mathrm{g}$ ) for male and female rats and their controls after $\mathbf{1 4}$ days of acute toxicity experiment, $n=5$. There were no significant differences between relative organs weight of treated rats and their control $(P>0.05)$

\begin{tabular}{cccc}
\hline Organs & & Treated group & Control group \\
\hline & Heart & $0.635 \pm 0.072$ & $0.677 \pm 0.064$ \\
& Lungs & $0.929 \pm 0.032$ & $0.918 \pm 0.075$ \\
Male Rats & Liver & $4.914 \pm 0.583$ & $5.304 \pm 0.849$ \\
& Kidneys & $0.856 \pm 0.103$ & $0.915 \pm 0.040$ \\
& Spleen & $0.534 \pm 0.062$ & $0.528 \pm 0.083$ \\
\hline \multirow{6}{*}{ Female Rats } & Heart & $0.510 \pm 0.060$ & $0.559 \pm 0.054$ \\
& Lungs & $0.908 \pm 0.030$ & $0.920 \pm 0.034$ \\
& Liver & $4.682 \pm 0.513$ & $5.066 \pm 0.811$ \\
& Kidneys & $0.864 \pm 0.092$ & $0.882 \pm 0.099$ \\
& Spleen & $0.462 \pm 0.039$ & $0.509 \pm 0.032$ \\
\hline
\end{tabular}


Table 4. Serum biochemical tests for rats receiving single dose $5 \mathrm{~g} / \mathrm{kg}$ of chloroform extract of Xanthium strumarium leaves and their controls after 14 days of acute toxicity experiment. the results represented as mean $\pm S D, n=5$. there were no significant differences between treated rats and their control $(P>0.05)$

\begin{tabular}{|c|c|c|c|c|}
\hline \multirow{2}{*}{ Biochemical test } & \multicolumn{2}{|c|}{ Male Rats } & \multicolumn{2}{|c|}{ Female Rats } \\
\hline & Treated group & Control group & Treated group & Control group \\
\hline $\begin{array}{c}\text { Blood Sugar } \\
\text { (mg/dl) }\end{array}$ & $97 \pm 10.36$ & $112.6 \pm 5.59$ & $91.4 \pm 9.34$ & $112.8 \pm 6.83$ \\
\hline $\begin{array}{l}\text { Blood Urea } \\
\text { (mg/dl) }\end{array}$ & $32.2 \pm 4.45$ & $27.4 \pm 5.59$ & $30.6 \pm 3.57$ & $25.8 \pm 4.81$ \\
\hline $\begin{array}{l}\text { Sr. Creatinine } \\
(\mathrm{mg} / \mathrm{dl})\end{array}$ & $0.53 \pm 0.097$ & $0.46 \pm 0.086$ & $0.51 \pm 0.091$ & $0.49 \pm 0.074$ \\
\hline $\begin{array}{c}\text { ALT (GPT) } \\
(\mathrm{U} / \mathrm{L})\end{array}$ & $39.3 \pm 4.086$ & $35.6 \pm 2.702$ & $36.5 \pm 3.701$ & $31.9 \pm 2.345$ \\
\hline $\begin{array}{c}\text { AST (GOT) } \\
(\mathrm{U} / \mathrm{L})\end{array}$ & $39.2 \pm 7.905$ & $27.7 \pm 9.055$ & $37.5 \pm 5.594$ & $33.6 \pm 5.403$ \\
\hline $\begin{array}{l}\text { ALP } \\
(U / L)\end{array}$ & $167.8 \pm 8.927$ & $171 \pm 4.207$ & $152.8 \pm 4.324$ & $153.0 \pm 8.018$ \\
\hline
\end{tabular}

\section{Discussion}

The present study showed that chloroform extract of Xanthium strumarium leaves has $L_{50}$ equals $3.07 \mathrm{~g} / \mathrm{kg}$. Other study showed that, $L_{50}$ of ethanol extract of Xanthium strumarium leaves was $1.5 \mathrm{~g} / \mathrm{kg}{ }^{(13)}$. However, the difference is not high between the two studies, the difference may be attributed to the nature of lands where the plant has planted, the extraction process conditions, and the solvent used was ethanol while in this study chloroform was used.

Acute toxicity study, where rats received oral single dose of $5 \mathrm{~g} / \mathrm{kg}$ aqueous solution of chloroform extract of Xanthium strumarium leaves, showed no mortality or signs of toxicity over the period of experiment. No significant changes in body weights of treated groups compared to their controls were observed $(P>0.05)$, relative organs weight of treated groups was non-significantly changed compared to that of the control groups $(P>0.05)$, and blood profile showed no significant changes in biochemical tests in comparison with normal controls $(P>0.05)$. The variations of the animal weights and organs weight between tested animals and their controls, reflect the toxic effect of substance (14). Significant difference in organ weight between treated and control animals may occur in the absence of any morphological changes ${ }^{(15)}$. There was no mortality or signs of toxicity were found in mice received extract of Xanthium strumarium at dose levels of 500$2000 \mathrm{mg} / \mathrm{kg}$, the initial and final weights of the animals were found to be similar to control (16). Another study of toxicity performed with chloroform and hexane soluble fractions of Xanthium strumarium reveals that the administration of a very high dose $(5 \mathrm{~g} / \mathrm{kg})$ for acute toxicity determination could not make any abnormal changes at gross as well as histopathological levels in the treated animals (17). Further studies on this subject are highly recommended.

In conclusion, this extract is toxic substance since it has low $\operatorname{LD}_{50}(3.07 \mathrm{~g} / \mathrm{kg})$, but the acute toxicity study showed no mortality or signs of toxicity, with non-significant changes in body weights, relative organ weights, and biochemical tests among treated groups compared to their controls. 


\section{Acknowledgement}

Authors would like to acknowledge the Department of Pharmacology at College of Medicine, Al-Nahrain University for offering the support at Phytotherapy Laboratory, especially Mrs Nada Ibrahim and Mr Ali Mussa as laboratory staff members. Special thanks to Iraqi Centre for Cancer and Medical Genetic Research, Al-Mustansiriyah University for offering support at animal house especially $\mathrm{Dr}$ Adnan Alsawak as staff member.

\section{Author contribution}

Dr. Alsabah: Collection of plant, extraction, performance of experiments. Dr. Abd: Supervision and writing of the manuscript. Dr. Al-Shammari: Supervision and editing of the manuscript.

\section{Conflict of interest}

Authors declare no conflict of interest.

\section{Funding}

No funding sources were found and the financial support was provided by the first author.

\section{References}

1. Kim H. Flavonoids inhibit VEGF/bFGF-induced angiogenesis in vitro by inhibiting the matrixdegrading proteases. J Cell Biochem. 2003; 89(3): 529-38. doi: 10.1002/jcb.10543.

2. Han $T$, Li HL, Zhang $Q Y$, et al. Bioactivity-guided fractionation for anti-inflammatory and analgesic properties and constituents of Xanthium strumarium L. Phytomedicine. 2007; 14(12): 825-9. doi: 10.1016/j.phymed.2007.01.010.

3. Menon GS, Kuchroo K, Dasgupta D. Interaction of microtubules with active principles of Xanthium strumarium. Physiol Chem Phys Med NMR. 2001; 33(2): 153-62.

4. Al-Ali A, Alkhawajah AA, Randhawa MA, et al. Oral and intra-peritoneal LD50 of thymoquinone, an active principle of NIGELLA SATIVA, in mice and rats. J Ayub Med Coll Abbottabad. 2008; 20(2): 25-7.

5. Di Pierro F, Menghi AB, Barreca A, et al. Greenselect Phytosome as an adjunct to a low-calorie diet for treatment of obesity: a clinical trial. Altern Med Rev. 2009; 14(2): 154-60.
6. Crowl DA, Louvar JF. Chemical process safety: fundamentals with applications. $3^{\text {rd }}$ ed. New Jersey: Prentice Hall; 2011.

7. Muslim NS, Nassar DZ, Abdalrahim FAA, et al. Antiangiogenesis and antioxidant activity of ethanol extracts of Pithecellobium jiringa. BMC Complement Altern Med. 2011; 12: 210.

8. Lorke D. A new approach to practical acute toxicity testing. Arch Toxicol. 1983; 54(4): 275-87. doi: 10.1007/BF01234480.

9. Aniagu SO, Nwinyi FC, Akumka DD, et al. Toxicity studies in rats fed nature cure bitters. African J Biotechnol. 2005; 4(1): 72-8.

10. Shah Ayub MA, Garg SK, Garg KM. Subacute toxicity studies of pendimethalin in rats. Indian J Pharm. 1997; 29: 322-4.

11. Bürger C, Fischer DR, Cordenunzzi DA, et al. Acute and subacute toxicity of the hydroalcoholic extract from Wedelia paludosa (Acmela brasiliensis) (Asteraceae) in mice. J Pharm Pharm Sci. 2005; 8(2): 370-3.

12. WHO. Cancer. World Health Organization; 2010. Retrieved 5 January 2011.

13. Chandel S, Bagai U, Vashishat N. Antiplasmodial activity of Xanthium strumarium against Plasmodium berghei infected Balb/C mice. Parasitol Res. 2012; 110(3): 1179-83. doi: 10.1007/s00436-011-2611-1.

14. Sireeratawong $S$, Lertprasertsuke $N$, Srisawat $U$, et al. Acute and subchronic toxicity study of the water extract from Tiliacora triandra (Colebr.) Diels in rats. Songklanakarin J Sci Technol. 2008; 30(5): 611-9.

15. Bailey SA, Zidell RH, Perry RW. Relationship between organ weight and body weight in the rat: what is the best analytical endpoint? Toxicol Pathol. 2004; 32(4): 448-66. doi: 10.1080/01926230490465874.

16. Piloto Ferrer J, Cozzi R, Cornetta T, et al. Xanthium strumarium L. extracts produce DNA damage mediated by cytotoxicity in in vitro assays but does not induce micronucleus in mice. Biomed. Biomed Res Int. 2014; 2014: 575197. doi: 10.1155/2014/575197.

17. Aranjani JM, Rao CM, Manuel A, et al. Acute and subacute toxicity of chloroform and hexaneextracts of root of Xanthium strumarium, Comp Clin Pathol. 2012; 21(6): 1223-30. doi: 10.1007/s00580-011-12695.

\footnotetext{
Correspondence to Dr. Atheer S. Alsabah E-mail: atheer_alsabah@yahoo.com Received Oct. $11^{\text {th }} 2018$ Accepted Dec. $28^{\text {th }} 2018$
} 